\title{
PUBLIC EVALUATIONS OF THE PRESIDENTIAL NOMINATION PROCESS
}

\section{Michael W. Traugott and Margaret Petrella}

\begin{abstract}
The evaluation of presidential nomination reforms has been the topic of elite discussion and debate, with little attention paid to popular evaluations. Public attitudes toward a number of reforms to the presidential nomination process were evaluated through survey data collected in 1988. The evaluations included campaign costs, debates, the influence of consultants, and the role of the media. The analysis suggests that there is a relatively high level of popular satisfaction with these dimensions of the current system. Popular concern about the nomination process is focused in two areas-the roles of money and the media. There is a strong suggestion that the movement toward regionalization of the calendar was respensive to partisan concerns in different regions of the country.
\end{abstract}

Presidential campaigns serve a dual role in the American electoral system. Like other campaigns in our democratic form of government, they provide a relatively rare opportunity for most citizens to interact, even indirectly, with their elected leaders or those who seek to represent them. At the same time, campaigns increase the salience of politics and stimulate an interest in political affairs that is not usually present in most citizens. Their primary purpose is to mobilize voters to go to the polls or, in smaller numbers, to participate in other forms of political activity (Campbell, 1966).

From the perspective of political elites and the party organizations, the prenomination phase of presidential campaigns provides the basis for selecting new leadership. In order to legitimate candidate selection and increase public confidence in the nominees, party leaders and other political activists have tried to broaden public participation in the process through a series of primaries and caucuses scheduled in the first six months of the presidential election year.

The current system of presidential primaries and caucuses reflects a number of fundamental tensions in the American electoral system. The selection of presidential nominees is a responsibility of the national party

Michael W. Traugott, Center for Political Studies, The University of Michigan, Ann Arbor, MI 48106-1248. Margaret Petrella, The Gallup Organization. 
organizations, but the process is conducted through a series of locally arranged events in which state parties primarily determine the eligibility criteria for getting on the ballot, the chronology of events, and the rules by which votes can be cast and allocated to delegate selection (Ceaser, 1982).

Over the last twenty years, there have been continuous "reforms" designed simultaneously to standardize and to open up the presidential nomination process, thereby increasing its responsiveness to the popular electorate. The goal of some reformers has been to increase participation in the process, whereas for others it has been simply to restore confidence in the system (Ladd, 1988). A number of these changes have produced their desired effects, but others have resulted in significant "unintended consequences" that have precipitated calls for still further reforms (Mann, 1985).

Many of the reforms were initiated in response to the difficulties that the Democratic party had with events surrounding its 1968 convention (Nelson, 1983). In response to public reaction to the broadcast of the Chicago convention, there was a movement toward popularly elected, pledged delegates. As a result, candidates have been forced to enter a growing number of primaries and caucuses in order to secure the nomination, rather than rely on networks of contacts with political bosses who can "deliver votes" at the convention in exchange for political favors. Thus, there has been a loss of some control by the national party and its elected leaders, although they have retained limited power through their selection as "super delegates."

The reforms most commonly linked to the Republican party came in the form of the Federal Election Campaign Act of 1974, enacted in the aftermath of Watergate, as a consequence of the disclosure of several large contributions to the 1972 Nixon reelection campaign (DiClerico and Uslaner, 1984). This legislation resulted in the public funding of presidential campaigns, including the associated requirements of limitations on candidate expenditures and the disclosure of contributions. Among other things, it was designed to reduce the role of "fat cat" contributors and force the candidates to broaden the financial basis of their support. The consequence of the financing reforms has been an increased emphasis on early fund-raising and the strategic allocation of money across the scheduled events.

While the disclosure requirement for contributions has had its intended effect, it is nevertheless the case that a candidate still requires large sums of money to secure the nomination. The cash flow during a prenomination campaign is particularly important, because the acceptance of matching public funds imposes limits on the amount that a candidate can spend in 
each state, as well as a limit on the total amount that can be spent prior to the nominating conventions. The fact that the total amount is less than the sum of the individual state totals places a premium on decisions about where and when to spend money, and candidates still have to spend an inordinate amount of their time on fund-raising (Orren, 1981).

Party loyalists have also expressed regional concerns. One involves the recurring issue of regional ticket balancing in the eventual slate of nominees, and the other has to do with various effects of geography on how the presidential nominee is selected. Because the chronology of the primaries and caucuses is largely determined by individual state decisions, some states have a greater weight in the selection process than would be expected by their population characteristics alone, and others have less (Bartels, 1988; Mann, 1985).

For example, the early scheduling of the Iowa caucus and the New Hampshire primary gives two relatively small and rural states a great deal of influence because early front-runners are identified there and subsequently receive disproportionate press coverage (Orren and Polsby, 1987). On the other hand, California - the most populous state in the nation-holds its presidential primary in early June on the same day that primaries are held for other state offices to be contested in November. Since 1972, each party's presidential nominees have generally been determined by this date; thus, what is an administratively efficient way for California to conduct its own electoral business has meant that its citizens have effectively had no say in the presidential selection process.

This "front-loading" of the calendar has tended to favor some candidacies by quickly elevating them to "front-runner" status, while effectively "winnowing" others because of poor finishes (Matthews, 1978). These effects of the calendar were of great enough concern among southern Democratic leaders that they organized an effort to schedule simultaneous events in their region on March 8,1988, in order to increase the region's influence on the process. And one of the Democratic contenders organized his campaign around a regional appeal in conjunction with "Super Tuesday," hoping to propel himself out of the pack.

Because of these reforms and what some see as a changing role of the national parties, presidential candidates have been forced to operate more independently, staffing their own campaign organizations and pursuing their own fund-raising activities. In order to develop and implement effective campaign strategies, candidates have increasingly turned to new and more sophisticated campaign technologies, including professionals who offer advice and consultation for a fee (West, 1984; Sabato, 1981). On the one hand, candidates employ pollsters to collect information on voter attitudes and perceptions. On the other hand, they employ advertising 
consultants to use this information in the design of the most effective themes and in the production of ads to communicate these messages (O'Keefe and Atwood, 1981).

In the new style of campaigning, the role of the media has also increased (Becker and McCoombs, 1978). Most of the candidates' contact with the electorate is indirect, as they attempt to mobilize support through advertising, events designed to structure their news coverage, or participation in a growing number of intraparty debates (Traugott, 1985; West, 1982). While there is still a lot of "retail" politics in Iowa and New Hampshire, the schedule for Super Tuesday in 16 geographically dispersed states magnified the candidates' need for TV in order to reach voters through ads. In many of those states, it was "wholesale" politics as usual, with most voters relying on the media for information about the personal characteristics and policy positions of the candidates.

What has been the net result of all these reforms? If the main purpose was to increase participation, they have not succeeded on two counts. First of all, levels of voter participation in the primaries and caucuses have remained characteristically low. Second, as has been the case since 1976, the candidates who are the best financed and well organized continue to be the most successful. And attempts to minimize the effects of "front-loading" have also been unsuccessful. Again in 1988, the eventual nominees appear to have surfaced long before the end of the process.

If a goal of the reformers was to increase confidence in and satisfaction with the presidential selection process, there has been little empirical evidence to demonstrate whether they were successful or not. Despite all of this maneuvering by political elites to revise the rules of the game, little research has been conducted on public responses to and evaluations of either these reforms or the current primary and caucus system. What few studies have been conducted have focused on various roles of the media in the prenomination phase of the campaign (Becker and McCombs, 1978; Pfau, 1987; Brunk and Fishkin, 1982). After this November, there will inevitably be calls for further reforms, as there have been following each quadrennial nomination cycle. While these policy decisions will continue to be made by political activists and elected officials, it is nevertheless important and useful to evaluate public reaction to the current system in order to guide decisions about reforming it.

\section{RESEARCH DESIGN}

As part of their ongoing collaboration in a series of studies entitled "The People, the Press, and Politics," The Gallup Organization has been conducting surveys of the American electorate for The Times Mirror 
Company since April 1987. ${ }^{1}$ The primary purpose of these surveys has been the development of a typology of electoral groups that goes beyond standard political labels and is based on beliefs and behaviors that drive political action (Times Mirror, 1987), an additional element of the content of these surveys is questions on popular evaluations of the presidential nomination process, including their representational function, the role and effectiveness of the press, and the importance of money, debates, and political consultants. ${ }^{2}$

The general form of the analysis involves an assessment of the electorate's "satisfaction" with the primary process as a way of determining the best-qualified nominees, operationalized as a dichotomous measure. ${ }^{3}$ As depicted in Figure 1, two sets of predictors were used to explain satisfaction: one based on the personal political attributes of each respondent and the other based on evaluations or assessments of various dimensions of the primary process that have been either the object or consequence of recent reform efforts.

Among the respondents' personal political attributes are their levels of

\section{EVALUATIONS OF THE PROCESS}

1. Importance of regional representation

2. Perceived effects of high campaign costs

3. Influence of advertising consultants/ pollsters

4. Influence of the media

5. Utility of the debates

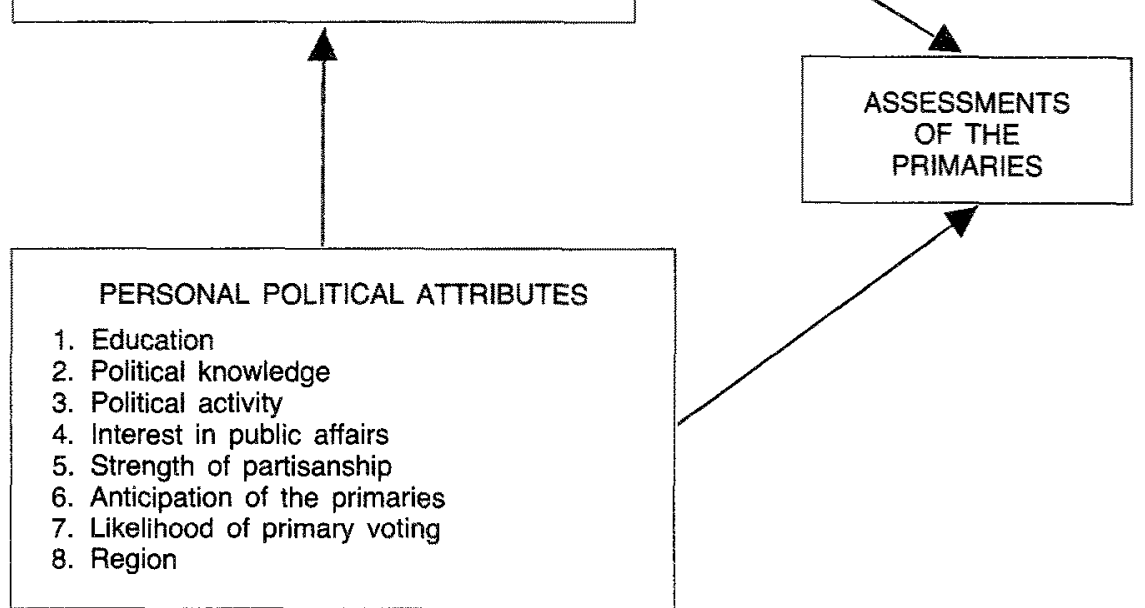

FIG. 1. A Schematic Representation of Factors Related to Public Evaluations of the Nomination Process. 
political knowledge and activity, interest in public affairs, strength of partisanship, anticipation of the primary contests, and likelihood of voting in a primary or caucus. In general, there are no differences between Democrats and Republicans in their assessment of the primary process, although a combination of region and party demonstrates differing levels of satisfaction. However, those who are strongly partisan are the most likely to believe they are capable of selecting nominees, as are those who are the most interested, involved, and looking forward to these events. In part, their political activism itself suggests that they would find any game is a good one to play, relative to those who customarily abstain.

But beyond these individual resources that they bring to almost any form of political behavior, members of the electorate also have assessments of specific rules and regulations that govern the current nomination system, as well as of the role of important institutional influences on the process (West, 1984). These evaluative criteria include the perceived effects of the costs of presidential campaigns, the role of the media and political consultants, the utility of debates, and the importance of regional representation on the eventual ticket. The specific operational form of each of these predictors is described in the Appendix. The analysis takes the form of an assessment of the incremental contribution of these evaluations, beyond personal political attributes, in explaining satisfaction with the primaries.

\section{RESULTS}

Since there has been little prior data collected in this area, the first level of analysis involves a presentation of the basic attitudes of the public toward various reforms or aspects of the process, including a look at how these attitudes vary by significant political characteristics of members of the electorate, such as their likelihood of voting in a presidential primary, strength of partisanship, and level of political knowledge. The data presented in Table 1 show that while the differences between likely primary voters and the adult population are slight, the differences for strong partisans and those who are most knowledgeable are more striking.

For example, two out of three Americans (64\%) are concerned that the high cost of presidential campaigns discourages good candidates from running. There is no difference in these attitudes by likelihood of primary vote or by strength of partisanship, but those who are most knowledgeable politically are much more likely to express this concern $(74 \%)$ than those who are least knowledgeable $(56 \%)$. There is also a positive relationship between levels of education and political activity and the belief that money has an effect on candidate quality. In addition, respondents who indicated that they made a contribution to a presidential candidate within the last 
TABLE 1. The Relationship Between Personal Political Attributes and Assessments of the Presidential Nomination Process

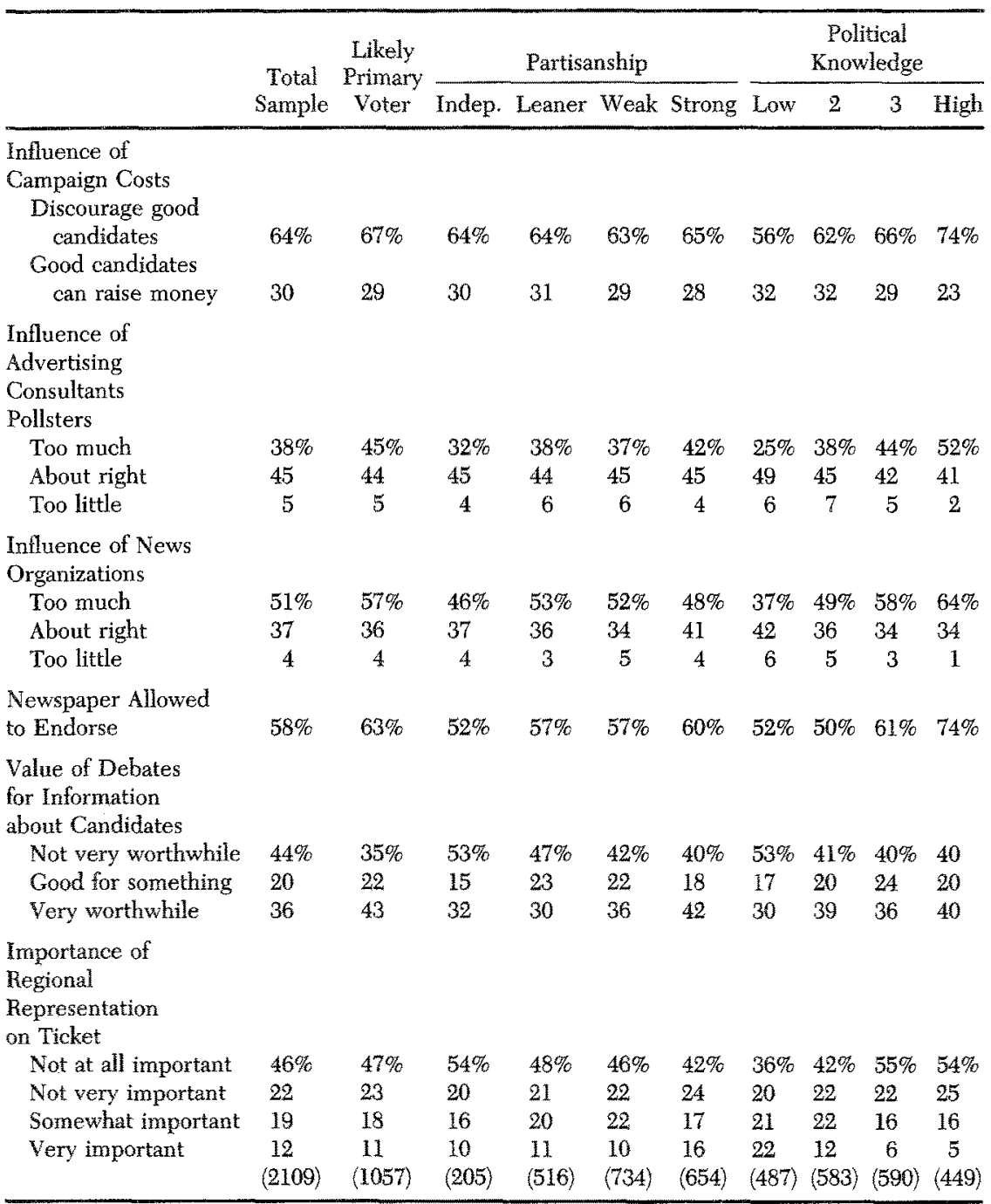

Percentages do not add to 100 because "Don't Know" responses have been omitted. Exact question wordings and details of index construction can be found in the Appendix.

year were more likely to be concerned about the effects of costs (72\%), probably a partial explanation for why they wrote a check in the first place.

On the question of the influence of advertising consultants and pollsters 
on which candidates become presidential nominees, the data presented in Table 1 show that almost as many say they have "too much" influence (38\%) as say they have "about the right amount" $(45 \%)$. Likely primary voters $(45 \%)$ are somewhat more concerned than the population as a whole, as are those who identify most strongly with a political party $(42 \%)$ and who have high levels of political knowledge (52\%). Furthermore, those with higher levels of education and political sophistication are also more likely to feel that advertising consultants and pollsters exert too much influence, perhaps reflecting their greater sensitivity to the most extreme and negative effects that these consultants might have.

Americans' views of the role of the media in the presidential nomination process are more complex. Two distinct measures were used to evaluate the role of the news media. One, assessing the influence of news organizations on which candidates become presidential nominees, implicitly reflects perceptions of both the quality and the quantity of coverage that the candidates receive and its effects on public evaluations of them. The other, related to endorsements, measures opinions of both a newspaper's right to support presidential candidates on the editorial page and the information value of such endorsement.

In the first case, a majority of those surveyed $(51 \%)$ felt that news organizations have "too much" influence on which candidates become presidential nominees. A somewhat higher proportion of likely primary voters feel this way, and there is also a positive relationship between levels of political knowledge and perceptions of influence. But the relationship with strength of partisanship is curvilinear. On the second matter, a clear majority of Americans ( $58 \%$ ) feel newspapers should be allowed to endorse a presidential candidate on their editorial page. Well-educated and politically active and attentive voters are most likely to feel this way. In both instances, these attitudes are presumably linked to the fact that these are the respondents who make the greatest use of news media and are the most avid newspaper readers. On the one hand, they value the information they receive from editorials; but they are also most likely to be familiar with the potential imbalance in the candidates' news coverage and its consequences for their viability.

In contrast to debates held during the general election campaign between the presidential nominees, intraparty debates during the prenomination phase have a lower information content for the public because the issue differences between candidates from the same party are frequently not as great as those between candidates from different parties. While they do provide some information about issue positions and the personal characteristics of the candidates, intraparty debates are more useful for increasing candidate recognition. 
In the January Times Mirror survey, six out of ten respondents reported having watched a debate between presidential candidates in the last year, although their evaluations of the utility of debates were only slightly higher than those of nonviewers. In general, the same positive relationships exist between political activity, interest, and involvement and the two questions that asked about the value of debates for information on where a candidate stands on the issues and on what kind of a person a candidate is. For ease of presentation and analysis, these two measures were transformed into a single index to reflect their combined utility to the respondents (see the Appendix). The data presented in Table 1 show that one-third (36\%) found the debates very worthwhile for both candidate and issue information, while $44 \%$ found them not very worthwhile. Likely primary voters, strong partisans, and the most knowledgeable were all more likely to find the debates worthwhile.

An attitudinal assessment of regional representation was measured directly by a question asking how important debates were to the respondents. Two-thirds of all those interviewed (68\%) did not attach any importance to this issue, and the likely voters felt no differently about this issue. In bivariate terms, this question was not related to satisfaction with the process either. In subsequent multivariate analysis, however, another indicator of regional concern-measured through ecological dummy variables that combined party identification and region-was significantly related to satisfaction with the process.

This multivariate assessment of the primary process looked at the relative explanatory power of the two sets of predictors: the personal political attributes of the respondents and their evaluations of the specific dimensions of the primary process discussed above. Additional measures of personal political attributes that were added to this part of the analysis include the respondents' education, anticipation of the presidential primaries, and levels of political activity and attention to public affairs. These measures are described in detail in the Appendix.

The base measure is whether or not respondents think that the presidential primaries are a good way of determining the best qualified nominees. ${ }^{3}$ Overall, six out of ten $(61 \%)$ expressed satisfaction with the current system, while a significant minority are either dissatisfied or uncertain about its effectiveness. In terms of their personal attributes, strength of partisanship and political interest and activity are most strongly related to favorable opinions of the process. Those who are looking forward to the process are more likely to express satisfaction with it, as are those most likely to vote in it. For both education and political knowledge, however, there is a curvilinear relationship with satisfaction. These data are presented in Table 2. 
TABLE 2. The Relationship Between Personal Political Attributes and Satisfaction with the Primary Process

\begin{tabular}{lrr}
\hline & $\underline{Y e s}$ & \\
Total Sample & $61 \%$ & $(2109)$ \\
Anticipating the Presidential Primaries & & \\
$\quad$ Not Looking forward to & $52 \%$ & $(901)$ \\
$\quad$ Looking forward to & $68 \%$ & $(1208)$ \\
Education & & \\
$\quad$ Less than high school & $58 \%$ & $(415)$ \\
High school graduate & $60 \%$ & $(782)$ \\
Some college & $67 \%$ & $(416)$ \\
College graduate & $62 \%$ & $(493)$ \\
Partisanship & & \\
Independent & $47 \%$ & $(205)$ \\
Leaner & $57 \%$ & $(516)$ \\
Weak partisan & $71 \%$ & $(734)$ \\
Strong partisan & $67 \%$ & $(654)$ \\
Likely Primary Voter & $66 \%$ & $(\mathbf{1 0 5 7})$ \\
Political Knowledge & & \\
Low & & \\
2 & $58 \%$ & $(487)$ \\
3 & $63 \%$ & $(583)$ \\
High & $64 \%$ & $(590)$ \\
Political Activity & $60 \%$ & $(449)$ \\
Low & & \\
Medium & $56 \%$ & $(678)$ \\
High & $63 \%$ & $(\mathbf{1 0 4 3})$ \\
Follow Public Affairs & $67 \%$ & $(388)$ \\
Hardly at all/ Only now and then & & \\
Some of the time & $53 \%$ & $(471)$ \\
Most of the time & $65 \%$ & $(727)$ \\
\hline Percentges do not & $65 \%$ & $(872)$ \\
\hline
\end{tabular}

Percentages do not add to 100 because "No" and "Don't Know" responses are omitted.

The exact question wording is, "Thinking about the presidential primaries, generally do you think they are a good way of determining who the best qualified nominees are, or not?"

In terms of the evaluative dimensions, the relationship between the perceived utility of debates and satisfaction with the process is by far the strongest. As indicated in Table 3 , the four other factors that are positively correlated with satisfaction include support for newspaper endorsements, lack of concern about the effects of campaign costs, the influence of news organizations, and the influence of political consultants and pollsters. For the latter two variables, the positive relationship suggests that public concerns about these external influences are associated with support for 
TABLE 3. The Relationship Between Assessments of the Primary Process and Satisfaction with It

\begin{tabular}{|c|c|c|}
\hline & $\underline{\text { Yes }}$ & \\
\hline Total Sample & $61 \%$ & $(2109)$ \\
\hline $\begin{array}{l}\text { Newspapers } \\
\text { Should not endorse } \\
\text { Should endorse }\end{array}$ & $\begin{array}{l}56 \% \\
65 \%\end{array}$ & $\begin{array}{r}(847) \\
(1262)\end{array}$ \\
\hline $\begin{array}{l}\text { Campaign Costs } \\
\text { Discourage good candidates } \\
\text { Good candidates can raise money }\end{array}$ & $\begin{array}{l}58 \% \\
69 \%\end{array}$ & $\begin{array}{r}(1535) \\
(574)\end{array}$ \\
\hline $\begin{array}{l}\text { Debates are } \\
\text { Not very worthwhile } \\
\text { Good for something } \\
\text { Very worthwhile }\end{array}$ & $\begin{array}{l}52 \% \\
62 \% \\
73 \%\end{array}$ & $\begin{array}{l}(884) \\
(454) \\
(771)\end{array}$ \\
\hline $\begin{array}{l}\text { News organizations have } \\
\text { Too little influence } \\
\text { About the right influence } \\
\text { Too much influence }\end{array}$ & $\begin{array}{l}49 \% \\
62 \% \\
62 \%\end{array}$ & $\begin{array}{r}(68) \\
(994) \\
(1097)\end{array}$ \\
\hline $\begin{array}{l}\text { Political consultants have } \\
\text { Too little influence } \\
\text { About the right influence } \\
\text { Too much influence }\end{array}$ & $\begin{array}{l}50 \% \\
62 \% \\
62 \%\end{array}$ & $\begin{array}{r}(114) \\
(1175) \\
(820)\end{array}$ \\
\hline $\begin{array}{l}\text { Importance of regional representation } \\
\text { on the presidential ticket is } \\
\text { Not at all important } \\
\text { Not very important } \\
\text { Somewhat important } \\
\text { Very important }\end{array}$ & $\begin{array}{l}61 \% \\
62 \% \\
64 \% \\
59 \%\end{array}$ & $\begin{array}{r}(1004) \\
(473) \\
(388) \\
(229)\end{array}$ \\
\hline
\end{tabular}

Percentages do not add to 100 because "No" and "Don't Know" responses are omitted.

popular participation in the direct election of delegates as a counterbalancing force. Regional representation is not monotonically related to satisfaction with the primary system.

The final step was a multivariate analysis to test the contribution of the evaluations of the primary process and satisfaction with it, beyond the respondents' personal political attributes. ${ }^{4}$ The results of two logistic multiple regressions are presented in Table 4 . In the first model, based solely on respondents' personal political attributes, there is substantial explanatory power that can be attributed to four attitudinal predictors, as evidenced in the $\chi^{2}$ and Somer's $D$ statistics. All of the independent variables except one are related to satisfaction in the expected direction. On the one hand, looking forward to the primary season, strength of partisanship, and interest in public affairs are positively related to 
TABLE 4. Logistic Regressions of Personal Political Attributes and Evaluations of the Primary Process and Satisfaction with It

\begin{tabular}{|c|c|c|}
\hline & $\begin{array}{l}\text { Model } 1 \\
\text { Personal Political Attributes }\end{array}$ & $\begin{array}{l}\text { Model } 2 \\
\text { Combined Model }\end{array}$ \\
\hline Intercept & -0.103 & -1.160 \\
\hline Education & $\begin{array}{rr}\text { beta }= & -0.029 \\
(\text { s.e. }= & 0.030)\end{array}$ & $\begin{array}{l}\text { beta }=-0.015 \\
\text { (s.e. }=0.030)\end{array}$ \\
\hline Political Activity & $\begin{array}{l}\text { beta }=0.064 \\
(\text { s.e. }=0.044)\end{array}$ & $\begin{array}{l}\text { beta }=-0.018 \\
(\text { s.e. }=0.045)\end{array}$ \\
\hline Political Knowledge & $\begin{array}{l}\text { beta }=-0.094^{*} \\
\text { (s.e. }=0.030)\end{array}$ & $\begin{array}{l}\text { beta }=-0.101^{*} \\
\text { (s.e. }=0.031)\end{array}$ \\
\hline Follow Public Affairs & $\begin{array}{l}\text { beta }=0.117^{*} \\
(\text { s.e. }=0.041)\end{array}$ & $\begin{array}{l}\text { beta }=0.059 \\
\text { (s.e. }=0.042)\end{array}$ \\
\hline Partisanship & $\begin{array}{l}\text { beta }=0.223^{*} \\
(\mathrm{~s} . \mathrm{e} .=0.033)\end{array}$ & $\begin{array}{l}\text { beta }=0.233^{*} \\
(\text { s.e. }=0.034)\end{array}$ \\
\hline Looking Forward to Primaries & $\begin{array}{l}\text { beta }=0.565^{*} \\
\text { (s.e. }=0.057)\end{array}$ & $\begin{array}{ll}\text { beta }= & 0.476^{*} \\
\text { (s.e. }= & 0.059)\end{array}$ \\
\hline Likely Primary Voting & $\begin{array}{ll}\text { beta }= & 0.032 \\
(\text { s.e. }= & 0.061)\end{array}$ & $\begin{array}{l}\text { beta }=-0.029 \\
\text { (s.e. }=0.062)\end{array}$ \\
\hline Eastern Democrat & $\begin{array}{l}\text { beta }=-0.066 \\
\text { (s.e. }=0.105)\end{array}$ & $\begin{array}{l}\text { beta }=-0.079 \\
\text { (s.e. }=0.107)\end{array}$ \\
\hline Midwestern Democrat & $\begin{array}{ll}\text { beta }= & 0.084 \\
(\text { s.e. }= & 0.104)\end{array}$ & $\begin{array}{l}\text { beta }=0.093 \\
(\text { s.e. }=0.106)\end{array}$ \\
\hline Southern Democrat & $\begin{array}{l}\text { beta }=-0.470^{*} \\
\text { (s.e. }=0.098)\end{array}$ & $\begin{array}{l}\text { beta }=-0.407^{*} \\
\text { (s.e. }=0.100)\end{array}$ \\
\hline Western Democrat & $\begin{array}{l}\text { beta }=-0.421^{*} \\
\text { (s.e. }=0.111)\end{array}$ & $\begin{array}{l}\text { beta }=-0.386^{*} \\
\text { (s.e. }=0.113)\end{array}$ \\
\hline Eastern Republican & $\begin{array}{l}\text { beta }=-0.125 \\
\text { (s.e. }=0.116)\end{array}$ & $\begin{array}{l}\text { beta }=-0.189 \\
(\text { s.e. }=0.118)\end{array}$ \\
\hline Midwestern Republican & $\begin{array}{l}\text { beta }=0.308^{*} \\
(\text { s.e. }=0.119)\end{array}$ & $\begin{array}{ll}(\text { s.e. }= & 0.348^{*} \\
(\text { s.e. }= & 0.121)\end{array}$ \\
\hline Southern Republican & 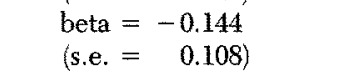 & $\begin{array}{l}\text { beta }=-0.129 \\
(\text { s.e. }=0.108)\end{array}$ \\
\hline Effects of Campaign Costs & - & $\begin{array}{l}\text { beta }=0.463^{*} \\
\text { (s.e. }=0.063 \text { ) }\end{array}$ \\
\hline Utility of Debates & - & $\begin{array}{ll}\text { beta }= & 0.360^{*} \\
(\text { s.e. }= & 0.032)\end{array}$ \\
\hline Newspaper Endorsements & - & $\begin{array}{l}\text { beta }=0.333^{*} \\
(\text { s.e. }=0.057)\end{array}$ \\
\hline News Organizations' Influence & - & $\begin{array}{ll}\text { beta }= & 0.057 \\
(\text { s.e. }= & 0.053)\end{array}$ \\
\hline Consultants' Influence & - & $\begin{array}{ll}\text { beta }= & 0.111^{*} \\
\text { (s.e. }= & 0.052)\end{array}$ \\
\hline Regional Representation & - & $\begin{array}{l}\text { beta }=-0.014 \\
\text { (s.e. }=0.027)\end{array}$ \\
\hline Regression Summary & $\begin{array}{l}\chi^{2}=290.78^{*} \\
14 D . F \\
\text { Somer's } D= \\
0.247 \\
(N=2092)\end{array}$ & $\begin{array}{l}\chi^{2}=506.46^{*} \\
20 D . F \\
\text { Somer's } D= \\
0.333 \\
(N=2092)\end{array}$ \\
\hline
\end{tabular}

* Significant at the .05 level or higher. ** Significant at the 10 level or higher. 
satisfaction. For the fourth predictor-political knowledge - the relationship is not in the expected direction, due to the curvilinearity observed in Table 2.

In addition, seven dummy variables were created, combining four regions of the country with the respondents' self-described attachment to a political party. These terms were added to the equation as indirect indicators of the regional concerns that had been invoked by political elites, particularly by southern Democratic leaders, and resulted in the orchestration of the Super Tuesday primaries and caucuses. Three of these dummy variables demonstrate clear differences from the missing indicator: being a western Republican. Both southern and western Democrats are significantly less satisfied with the primaries, suggesting that the elites' efforts might indeed have reflected concerns of their party members, and respondents from the West (more of whom reside in California) might harbor the same concerns about their role in the presidential selection process. Midwestern Republicans are relatively more satisfied, all other things being equal.

When the measures of evaluations of the different dimensions of the current system are added, the explanatory power of the model is increased significantly. The value of $\chi^{2}$ increases by more than $70 \%(p<.001)$, and the value of $D$ increases by almost one-third. Two of the personal political attributes remain important predictors of satisfaction in the expected fashion-strength of partisanship and looking forward to the primaries-while the sign for the relationship involving political knowledge remains reversed. The incremental variance explained comes from perceptions of the utility of the debates, the influence of advertising consultants and pollsters, the value of newspaper endorsements, and views on the effects of campaign costs.

\section{CONCLUSIONS}

The data presented here indicate that there is a relatively high level of satisfaction with the current primary system; overall, the population feels that primaries are a good way of choosing the best-qualified nominees. Political elites and public policy makers should be heartened by the fact that those who are most active and most likely to be involved in the process are the ones who are most satisfied with it.

To the extent that the survey measured continuing concerns about the nomination process, concerns are focused on two different areas: the roles of money and the media. With regard to the first topic, the public feels that the high costs of running a presidential campaign may be discouraging good candidates from pursuing the office. In Representative Pat Schroeder's case, 
for example, considerations of the size of the necessary budget and the effort that would be required to raise the funds were important factors in her decision not to become a presidential candidate. Yet campaign finance is an area of public policy in which further legislative action could be taken, These data suggest that thought should be given to making more money available early in the process so the pool of candidates can be increased and the public can be exposed to a wider range of choices before the inevitable winnowing takes place.

It is not easy for public policy makers to deal with the public's concern about the role of the media or the influence of paid consultants in the presidential selection process, because there are no legislative remedies. Public perceptions about the institutional role of the medis in the process remain problematic because of the independence of news organizations. While the public values newspaper endorsements of presidential candidates, the Times Mirror/Gallup surveys have consistently shown that the public is more generally concerned about the influence of news organizations in American society. However, there is little that public policy makers can do to alter the role of the media.

Given the fact that people seem to find intraparty debates useful, some actions could be taken to ensure that they remain an integral part of the process. Instead of focusing on concerns about appropriate sponsorship, perhaps more attention should be given to their frequency and timing, with an emphasis on maximizing candidate exposure.

This analysis contains the strong suggestion that the movement toward regionalization of the calendar, as embodied in the Super Tuesday primaries and caucuses, was responsive to a genuine concern of partisans from different areas of the country. Additional measures to counteract the effects of front-loading and the idiosyncrasies of the chronology would probably be well received by the public. Even though political elites have discussed the consequences of Super Tuesday, for example, there has been no published research on how the electorate reacted to these events.

While the reforms of the system are the result of actions taken by political elites - not necessarily in response to strong public outcries for change-little systematic attention has been devoted to public evaluations of the changes. One way to assess the efficacy of the reforms is to determine whether they are accompanied by increased public confidence or satisfaction with the new system. The analysis reported here suggests that issues related to the calendar and geography, as well as to public finance, would be fruitful areas in which to conduct future research.

Authors' Note: an earlier version of this article was prepared for delivery at the Annual Meeting of the American Association for Public Opinion Research, May 
19-22, 1988, Toronto, Canada. At that time, Traugott was at The Gallup Organization, directing the Times Mirror survey project.

\section{NOTES}

1. The analysis presented here is based on surveys conducted in January 1988 by The Gallup Organization for The Times Mirror Company. We are grateful for the methodological assistance of Jack Ludwig and the clerical assistance of Cheryl Carlomagno. However, the analyses and interpretations are solely the responsibility of the authors.

2. This analysis is based on a national survey conducted between January 8 and January 17 , 1988 that involved personal interviews with 2,109 individuals 18 years of age and older. The average interview length was approximately one hour. The survey is based on a replicated probability sample down to the block level in the case of urban areas and to segments of less populous areas. Below the block level, a systematic selection of individual respondents was used. For purposes of evaluating statistical significance based on this design, a sampling tolerance of \pm 3 percentage points should be used. In addition to sampling error, question wording and other practical difficulties in conducting surveys can introduce error or bias into analysis of the results.

3. The exact question wording was, "Thinking about the presidential primaries, do you think they are a good way of determining who the best qualified nominees are, or not?" The responses were converted to a dummy variable by maintaining the category "yes, they are" and combining the responses "no, they are not" and "don't know."

4. The multivariate analysis utilized the LOGIST procedure in SAS to perform logistical regression (Hastings, 1986). Two separate regressions were run in which the first set of variables was entered, and then the complete second set.

\section{REFERENCES}

Bartels, Larry M. (1988). Presidential Primaries and the Dynamics of Public Choice. Princeton, NJ: Princeton University Press.

Becker, Lee B., and McCombs, Maxwell E. (1978). The role of the press in determining voter reactions to presidential primaries. Human Communication Research 4: 301-307.

Brunk, Gregory G., and Fishkin, James A. (1982). Media coverage of presidential candidates: A study of popularity prior to the 1976 national nominating conventions. Communication Research, 9 (4): 525-538.

Campbell, Angus (1966). Surge and decline: A study of electoral change. In Campbell et al. (eds.), Elections and the Political Order. New York: Wiley.

Ceaser, James W. (1982). Reforming the Reforms. Cambridge, MA: Ballinger Publishing Company.

DiClerico, Robert E., and Uslaner, Eric M. (1984). Few Are Chosen: Problems in Presidential Selection. New York: McGraw Hill.

Grassmuck, George (1985). Before Nomination: Our Primary Problems. Washington, DC: American Enterprise Institute for Public Policy Research.

Hastings, Robert P. (ed.) (1986). SUGI Supplemental Library User's Guide, Version 5 Edition. Cary, NC: SAS Institute Inc. 
Ladd, Everett C. (1988). The myths of modern campaigns: Misstating the problems. Public Opinion, May/June: 59.

Mann, Thomas E. (1985). Should the presidential nominating system be changed (again)? In George Grassmuck (ed.), Before Nomination: Our Primary Problems. Washington, DC: American Enterprise Institute for Public Policy Research.

Matthews, Donald R. (1978). Winnowing: The news media and the 1976 presidential nominations. In James David Barber (ed.), Race for the Presidency. Englewood Cliffs, NJ: Prentice-Hall.

Nelson, Michael (1983). The presidential nominating system: Problems and prescriptions. In Richard J. Zeckhauser and Derek Leebaert (eds.), What Role for Government? Durham, NC: Duke University Press.

O'Keefe, Garrett J., and Atwood, L. Erwin (1981). Communication and election campaigns. In Dan D. Nimmo and Keith R. Sanders, Handbook of Political Communication. Beverly Hills: Sage Publications.

Orren, Gary R. (1981). Presidential campaign finance: Its impact and future. Commonsense 4(2): 50-66.

Orren, Gary R., and Polsby, Nelson W. (1987). Media and Momentum: The New Hampshire Primary and Nomination Politics. Chatham, NJ: Chatham House Publishers, Inc.

Pfau, Michael (1987). The influence of intraparty political debates on candidate preference. Communication Research 14 (6): 687-697.

Sabato, Larry J. (1981). The Rise of Political Consultants. New York: Basic Books.

Times Mirror (1987). The People, the Press b Politics. Los Angeles: The Times Mirror Company.

Traugott, Michael W. (1985). The media and the nominating process. In George Grassmuck (ed.), Before Nomination (1985).

West, Darrell M. (1984). Making Campaigns Count: Leadership and Coalition Building in 1980. Westport, CT: Greenwood Press.

\section{APPENDIX}

Part of the analysis was based on the operationalized measures described below.

\section{Political Knowledge Index}

This additive index classifies respondents on the basis of the number of correct responses to the following questions about knowledge of politics and current affairs:

Q. 22. Do you happen to know whether the U.S. is supporting the government in Nicaragua, or is the U.S. supporting the rebels who are opposing the Nicaraguan government?

Q. 23 Do you happen to know how many women, if any, sit on the U.S. Supreme Court?

Q. 24. (HAND RESPONDENT CARD G) Do you happen to know which of these men is currently the Speaker of the U.S. House of Representatives? 


Index of
Political Knowledge
Low
2
3
High

\begin{tabular}{c}
$\begin{array}{c}\text { Number of } \\
\text { Correct Responses }\end{array}$ \\
\hline 0 \\
1 \\
2 \\
3
\end{tabular}

\section{Political Activity Scale}

This index was created from the following question:

We would like to find out about some of the things people do during a presidential campaign. Which of the following have you done, if any, within the last year or so?

a. Watched a debate between presidential candidates?

b. Contributed money to a presidential candidate?

c. Contributed money to a political party organization?

Respondents were classified according to the number of political activities in which they have participated:

\begin{tabular}{c}
$\begin{array}{c}\text { Index of } \\
\text { Political Activity }\end{array}$ \\
\hline Low \\
Medium \\
High
\end{tabular}

$\begin{gathered}\text { Number of } \\ \text { Political Activities }\end{gathered}$
0 or 1
2
3

\section{Partisanship}

The partisanship variable measures strength of party affiliation by "folding" the standard seven-point scale of party identification.

Independent

A self-identified Independent who refuses to lean to either party

Leaner

An Independent who leans to either the Republican or Democratic party

Weak Partisan A self-identified Republican or Democrat who has weak ties to their party

Strong Partisan A self-identified Republican or Democrat who has strong ties to their party

\section{Likely Primary Voter}

A Likely Voter Scale was constructed by classifying respondents on the basis of past voting behavior, voter registration, and likelihood of voting in the future. Index scale values were assigned as follows: 
Voted in 1984

yes $=1$ point

Registration Status

Currently registered or plan to register $=1$ point

Frequency of Voting

Always or nearly always $=1$ point

\section{Question Number}

Q. 49

Q. 50

Q. 52

Respondents not currently registered to vote, who also say they do not plan to register for the next presidential election, were given an automatic zero score on the Likely Voter Index, regardless of their responses to other questions used to form the index.

A respondent who had the maximum possible points ( 3 points) on the Index was classified as a "Likely Voter." A "Likely Primary Voter" is defined as a Likely Voter who plans to vote in either the Republican or Democratic primary.

\section{Value of Debates}

The construction of this measure involved cross-tabulating respondents' scores on two related questions:

How good of a job do the debates do for you in providing information on where a candidate stands on the issues? Do they do an excellent job, a good job, a fair job, or a poor job?

How good of a job do the debates do for you in providing information on what kind of a person a candiate is? Do they do an excellent job, a good job, a fair job, or a poor job?

The answer categories were collapsed, so that "Excellent" and "Good" ratings were combined in a category called "useful." "Fair" and "Poor" ratings were combined as "not very useful." The Value of Debates scale was then constructed as follows:

\section{Value of Debates}

Very Worthwhile: Debates were useful in providing information on both where a candidate stands on issues and on what a candidate is like personally,

Good for Something: Debates were useful in providing information on either where a candidate stands on issues or on what a candidate is like personally.

Not Very Worthwhile: Debates were not useful in providing information on either where a candidate stands on issues or on what a candidate is like personally.

Additional details about the construction of specific measures are available from the authors. 